\title{
THE CIVIL WAR AS REVOLUTIONARY REENACTMENT: WALT WHITMAN'S "THE CENTENARIAN'S STORY"
}

\author{
EDWARD TANG
}

IN RECENT YEARS, Drum-Taps (1865) has drawn increasing attention from literary critics as well as from historians of American culture. Some scholars have used Drum-Taps to evaluate Whitman's experiences nursing wounded soldiers in Washington, D.C., while others have focused on his crafting of thematic and aesthetic patterns that allowed him to transform his Civil War experience into art. ${ }^{1}$ Even though it is one of the longer pieces in Drum-Taps, however, "The Centenarian's Story" has not received much notice. The poem tells of an aged revolutionary war veteran who recalls for a young Union Army volunteer a battle scene from 1776. Many critical works have given "The Centenarian's Story" only passing mention even though it is the only piece in Drum-Taps that principally links the Revolution to the Civil War, an important rhetorical strategy employed by many Americans in the nineteenth century as they attempted to comprehend their sectional conflict. In this essay, I propose a cultural and historicist reading of "The Centenarian's Story" to highlight how it coincided with other popular literature of the time that evoked the presence and memories of revolutionary war veterans. In doing so, I contend that these lesser-known writings both complement and complicate our understanding of Whitman's sense of historical memory during the Civil War.

David Reynolds and Betsy Erkkila have been on the forefront of tracing the political, cultural, and historical influences on Whitman's work. In Beneath the American Renaissance (1988), Reynolds discloses that Whitman, like other major authors, was well acquainted with popular writings that ranged from religious and reform tracts to sensationalist literature and bawdy humor. In light of these influences, Reynolds notes as well in Walt Whitman's America (1995) that, unlike the early editions of Leaves of Grass (1855, 1856, 1860), the poems in Drum-Taps are quite conventional pieces. A variety of reasons explain this shift toward more "acceptable" poetry. Whitman first and most obviously desired a broader acceptance in the literary marketplace after his lyrical experiments in Leaves of Grass left him with tepid sales. His changing style also coincided with his participation in the federal bureaucracy from 
1863 to 1873 when he obtained positions in the army paymaster's and attorney general's offices as well as the Bureau of Indian Affairs. He had become part of the institutional mainstream, even venturing so far as to admire the greatly maligned Andrew Johnson. ${ }^{2}$

Whitman was mindful too of how Americans celebrated their revolutionary past through commemorative rhetoric. Erkkila convincingly demonstrates in Whitman the Political Poet (1989) the bard's use of revolutionary ideology and his own family genealogy in his work to create a new democratic poetics. In distinguishing between Leaves of Grass and Drum-Taps, Erkkila observes: "If in the prewar period Whitman had viewed himself as a poet-prophet, mythically embodying democracy and the revolutionary traditions of the past, during the war years he came to see himself as a kind of poet-historian, preserving a record of the present moment for future generations." Seeing amputated limbs or listening to young men's howls and groans in the hospital, she surmises, must have pushed Whitman into less abstract and more historical desires to report on the ugliness of the war's destruction, if not on the failing experiment in democratic self-rule. Erkkila also associates Whitman's tendency toward stylistic convention with a pattern that several poets adopted in the wake of political catastrophe. As she remarks: "Like Milton after the collapse of Cromwell's Commonwealth, Blake after the failure of the French Revolution, and Pound after World War I, Whitman moved during the war years away from the visionary poems of his early period toward what Pound would call the "poem including history."'3

I would add to these analyses that Whitman's poetic formalism, especially in "The Centenarian's Story," also stemmed from conventional themes deeply rooted in remembrances about the Revolution that pervaded the nation throughout the nineteenth century. Several scholars already have argued that in interpreting the Civil War as history, Whitman, along with Lincoln and other political leaders, turned to the founders' reassuring ideals and rhetoric to make sense of political disunion. ${ }^{4}$ But Whitman, I suggest, also relied on popular writings with their prescribed forms and historical sensibilities that saturated the nation's antebellum commemorative culture. In the impassioned battles of sectional rivalries and eventual civil war, popular literature gave voice to an enduring perception of continued success and possibilities that the revolutionary past bestowed upon its citizens in the face of impending despair or defeat. Alongside this hopefulness, however, "canonical" and popular writers also questioned how well the nation actually fared in light of the Revolution's legacies. Nathaniel Hawthorne's short story "My Kinsman, Major Molineux" (1832), Frederick Douglass's speech "What to the Slave is the Fourth of July?" (1855), or Herman Melville's novel Israel Potter: His Fifty Years of Exile (1855) demonstrate how these authors critiqued their democratic society's shortcomings or outright failures. Whitman often conveyed in prose and poetry his frustration at 
how softheaded politicians and corrupt institutions constantly undermined the ideals of democracy. ${ }^{5}$

The Revolution and its legacies of liberty and equality thus offered the nation's citizens a problematic bequest, one explored by many conventional writers between the 1820 s and 1860s. From this perspective, the variety of popular methods that celebrated, modified, or contested the nation's revolutionary traditions were just as influential in Whitman's poem as his employment of the founders' cherished ideals themselves. Short stories, poetry, essays, newspaper editorials and other genres in this era performed valuable cultural work by providing Whitman with several modes of literary expression to adapt in "The Centenarian's Story."

\section{Generational Memories}

To fully appreciate "The Centenarian's Story," we must first consider how the larger impressions of the Revolution affected practically everyone in Whitman's generation. In this sense, the poet drew upon an already existing tradition in which the nation's citizenry wanted to document their revolutionary antecedents for future generations and to legitimate their young republic within the surety of its glorious past. Alongside the rampant mythmaking about the founders, many Americans who came of age in the decades after the Revolution comprehended the revolutionary past within the intimate circles of family and community. ${ }^{6}$ Older generations of parents, grandparents, other relatives, and community acquaintances imparted firsthand reminiscences of the war to their progeny, creating networks of oral histories well into the first half of the nineteenth century. The younger, post-revolutionary generations in the meantime imbibed, reinterpreted, and debated their sires' legacies to shape their own historical outlooks and future aspirations. ${ }^{7}$ What sociologist Maurice Halbwachs calls "the living bond of generations" suggests an imagined continuity between the past and present created from communal tales and remembrances. This "lived history" consequently provides a riveting framework by which to personalize the past for storytellers and listeners alike. ${ }^{8}$

Along with Betsy Erkkila, M. Wynn Thomas and George Hutchinson have evaluated how Whitman made use of his personal relations with his family during the Civil War to give narrative shape and historical context to the nation as a larger metaphorical family. As Thomas notes, Whitman's commitment to the war derived chiefly from his brother George's experiences on the battlefront as well as the Whitman family's anxieties for his safety. Hutchinson asserts that the poet, by visualizing the nation as a troubled white family much like his own, failed to account for including African Americans as mutual participants in that broader political family. ${ }^{9}$ Expanding on these arguments, I 
would emphasize the extensive intermediary tissues of memory that connected Whitman and his concept of a national family to other writers, and implicitly readers, within antebellum popular culture. Whitman shared in a literary environment that affected how many of its authors viewed the Revolution and a looming civil war as a family affair precisely because they processed the nation's past, present, and future through family and community histories.

If Whitman sought to confirm his Civil War as history, he did not have to look far for conventional models of democratic expression that envisaged the Revolution as history. Newspapers and periodicals contained numerous observations on the revolutionary past, recording nostalgic memories that underscored the overlapping of generations over time. The more conscientious among the younger generations venerated revolutionary participants with great sentiment and gratitude within their local circles of family and community. Reflecting on the death of a veteran in 1827, one writer confessed in The Casket about his boyhood days: "'Narrative old age' seldom finds a listless auditor in youth, and . . gladly would I scamper over the fields, to catch with greedy ears the loquacious veteran's vivid description [of the war]," all the while skipping school. In 1841, a mill worker in Lowell, Massachusetts penned her thoughts in The Lowell Offering on seeing revolutionary veterans at a July Fourth celebration: "I was carried, in imagination, to the time when these hoary-headed veterans stood on the battle-field . . . and I could not refrain from shedding tears, - but they were tears of gratitude . . . that they were here standing as the memorials of the past." One Lewis R. Hamersly concluded in Godey's Lady's Book in 1843: "The Revolution ... was an event of the last age; and there are enough 'veterans of half a century' yet lingering with us, to link the past and the present generation as closely together as though both were but a single succession of men." These intimate connections to a generational past served to anchor the younger members' sense of belonging to wider associations of memories and collective identities amid the drastic social transformations occurring throughout the nineteenth century. ${ }^{10}$

Along with supplying sentimental memories, the revolutionary generations were also teachers who presented valuable lessons for the future. The post-revolutionary generations looked upon these elderly personages as experienced people who could pass on knowledge, advice, and assurance to their descendants. Niles' Weekly Register observed in 1820: "Nearly all the great actors in 1776 , have made their exit to 'another and a better world'; but some venerable men yet remain to bless our land with their presence and point the path to political rectitude."11 The editor Hezekiah Niles was unequivocal in his appreciation for the revolutionary past: it would steer the nation's more youthful members from present and future mistakes and uncertainties. That so few of these revolutionaries were still living intensified the import of his observation 
for younger generations of Americans. This idealized relationship among the different generations also had reciprocal advantages. Not only would the elderly offer moral lessons and guidance, but also, by telling past experiences, the yarn-spinners themselves would perpetuate their own identities through the memories of their listeners. ${ }^{12}$

Within antebellum popular literature, ordinary citizens' past sacrifices became conceptual lessons of freedom and democracy that filtered throughout the wider culture. In her 1829 short story, "The Soldier of the Revolution," Sarah J. Hale elaborated on the significance of revolutionary memories. "[W] hoever had heard, or read the narratives of the veterans of our revolutionary war," she wrote, "must have remarked that they dwell not so much on the detail of the battles and skirmishes in which they were engaged, as on the effect those actions had in deciding the contest in favor of liberty and independence." The previously mentioned Lewis R. Hamersly likewise observed in his piece: "[W]e should especially preserve the memory of the humbler participators in our war of independence ... found in the principles and results of the war; in the new dignity which it gave to the mere individual; in the new importance which it attached to man as man; in the popular tendencies which it gave to the age." As these writers noted, the revolutionary past validated the democratic present, building through communal memories the reverence for unsung heroes. ${ }^{13}$

Despite this collective sense of historical continuity provided by the revolutionary generations, the antebellum era also marked the passing of the few remaining veterans, affecting how tales of revolutionary struggles and triumphs would thereafter be told and interpreted. Niles' Weekly Register calculated in 1826 that less than three hundred revolutionary officers were still alive. "Ten years hence," the paper continued, "in all probability, twenty will not remain." ${ }^{14}$ In 1838, Abraham Lincoln called attention to this generational shift in his "Address to the Young Men's Lyceum." He attested that "nearly every adult male had been a participator" in the battles of the Revolution. "The consequence was," he added, "that of those scenes, in the form of a husband, a father, a son or a brother, a living history was to be found in every family ... a history, too, that could be read and understood alike by all." 15 Even as Lincoln acknowledged the intimate, democratic manner by which to comprehend the revolutionary past, he conspicuously noted it with italics as no longer existing. That this living past was quickly vanishing incited a longing among the post-revolutionary generations for a nostalgic comfort that coexisted uneasily with troubling doubts about the future and their own worthiness to sustain such high expectations derived from the nation's founding. Several months before Lincoln's speech, financial panic hit the nation in 1837, causing one poet in the Southern Literary Messenger to lament: 
When we reflect upon the men of old,

Who boldly thundered forth the rights of men

In Britain's ear . . .

May we not ask if this our modern race

Had done so well or wisely in their place? ${ }^{16}$

The Revolution and its heroes presented virtually unattainable standards by which to measure the nation's progress that the younger generations felt keenly obligated to uphold. As a number of authors maintained, the responsibilities arising from this history were personalized as well since they came as part of almost every family's social identity.

If some writers had reservations about the victorious ascension of democracy in their own times, a handful of surviving veterans themselves contested the overall sense of national confidence garnered from the revolutionary past. On July 4, 1826, Americans commemorated the jubilee anniversary of the Declaration of Independence and mourned the near-simultaneous deaths of John Adams and Thomas Jefferson. Shortly after the jubilee celebrations had ended, however, a few elderly veterans were discovered living out their days in thankless poverty. As Niles' Weekly Register observed that year, twenty-five aged officers from Maine and Massachusetts suffering "indigent circumstances" still retained "old promissary notes" that remained unpaid to them. Though never financially compensated for their services, the periodical continued, "they cannot swear they are paupers; and beg in their old age, of the country of which, in their youth, they were the salvation." In New York, fourteen veterans composed a letter of grievance to Congress about the slow distribution of pensions, hoping that "succeeding generations would not impiously suffer the dark mantle of forgetfulness." "[W]e now demand ... that pittance," they angrily wrote, "to which ... we are entitled." Other revolutionary veterans still struggled with poverty and other hardships in South Carolina, although "none of them have ever applied for a pension." These reports in Niles' Weekly Register, albeit fewer in number than the more popular, sentimental recollections of the war, intended to strike a chord of sympathy, if not alarm at the deprived conditions in which these veterans spent their last days. ${ }^{17}$

The veterans' grievances against the nation's forgetfulness coincided more intimately with families' grieving over their elders' deaths and unrecognized sacrifices. As personal histories of the revolutionary past, these stories of loss and suffering recounted through their sires' memories literally affected the home and family. One short story, "The American Soldier," appeared in an 1826 edition of The Casket, telling a sentimental tale of two daughters mourning the oncoming demise of their poverty-stricken father. Narrated by a family friend, the story begins with a poem that chastises the nation's disregard of its veterans: 
Behold a hero who in battle stood,

And shed for freedom virtue's sacred blood;

$\mathrm{He}$ dies neglected in old age forlorn,

The poor man's pity, and the rich man's scorn:-

Behold and weep-pour forth the grateful tear,

For valour slumbers in oblivion here.

As death nears, the old soldier imagines past scenes of glory and honor for the bereaved gathering, only to lament that he will now pass away "in an obscure cottage." The narrator makes clear her moral purpose: "The remembrance of that night will require a long time to be eradicated from my memory; it will serve to tell me how a brave man was left to struggle with misfortune, and die neglected, who had fought and bled for the independence of his country." Saddened yet determined to remember this forlorn scene, the narrator implies it will prompt her to action. Despite its despairing tone, the conclusion reveals her strengthened resolve to commemorate the veteran's past and recount it to a larger audience. Her desire rests on the assumption that this tale not only will reinvigorate orally recounted remembrances, but also will stir others to call the nation on its ingratitude and forgetfulness. ${ }^{18}$

Novelists, historians, poets, and essayists continually attempted to highlight the significance of aging veterans for a forward-looking society that might prove neglectful of their past deeds and sacrifices. Sarah Hale declared in "The Soldier of the Revolution" that the "generous devotedness of the American soldiery to the principles of liberty and equal rights, and their prompt obedience to civil government, have no parallel in history." She added: "They have never been adequately rewarded, but let them be gratefully remembered. They deserve to have their deeds the theme of story, and of song." Samuel Goodrich reminisced about his own childhood in 1856: "Every old man, every old woman had stories to tell, radiant with the vivid realities of personal observation or experience." "The time which had elapsed since these events [of the Revolution]," he continued, "had served only to magnify and glorify these scenes, as well as the actors, especially in the imagination of the rising generation." Goodrich, as part of this rising generation, would then put his memories and imagination to use, creating a series of children's books narrated by the fictional Peter Parley. Introducing Parley's adventures in The Tales of Peter Parley About America (1829), Goodrich proposed to his reading audience that the Revolution undoubtedly was "the most interesting part of our history." In 1842, Whitman himself played into the popular sentiments about the revolutionary past in "The Last of the Sacred Army," a short story for the Democratic Review. The tale's narrator falls asleep on a Fourth of July afternoon and dreams of a crowd paying its last respects to an aged revolutionary veteran. The story's moral coincides with several aspects of historical remembrance articulated in other popular writings. A "philosopher" among 
the gathering advises the narrator still in his reverie: "Nothing more becomes a nation than paying its choicest honors to the memory of those who have fought for it, or labored for its good. By thus bringing up their examples before the eyes of the living, others are incited to follow in the same glorious path." 19

Poets in particular often aspired to unveil the contributions of everyday citizens from revolutionary times to track the emergence and development of a democratic political culture. The prevalent curiosity about and availability of firsthand sources from the war, they insisted, especially would lend credence to the success of the democratic experiment. A whole body of poetry on revolutionary participants appeared in popular literature during the late 1830 s and early 1840 s, a period when Whitman began contributing stories to the Democratic Review. Much of this work on aged veterans established the democratic themes and contexts of remembrance that Whitman would later adapt and transform in "The Centenarian's Story." 20 In 1834, for example, Atkinson's Casket published "The Veteran and the Child." The work replays a familiar scene in which an elderly man recalls war stories to his grandchild:

The prattler had stirr'd in the veteran's breast,

The embers of fire that had long been at rest.

The blood of his youth rush'd anew through his veins;

The soldier returned to his early campaigns -

His perilous battles at once fighting o'er. . . . ${ }^{21}$

As in this piece, many of the following poems reconfigure the oral memories of past glory and patriotism, the reviewing of a life's legacy to inform the younger generations. The works' sentimental and nostalgic tones divulge the post-revolutionary writers' sense of familial loss, of social transitions completed and impending, as well as the need to draw inspiration from the past.

One particular topic involves veterans returning to old haunts that stir their memories of the war, as evidenced in Melzar Gardner's "The Old Soldier Revisiting the Scene of His Early Struggles." Published in an 1838 Democratic Review, it reveals through a footnote that a newspaper clipping had inspired the work, in which a veteran visits Bunker Hill "to take a last farewell." Gardner transforms the old man's reported musings into poetic form:

A weary way! yet, once again

My foot-print marks this holy soil;

This - this, the consecrated plain,

Where patriot hands by painful toil

Did Freedom's earliest altar rear;-

'Twas here our untaught army stood. . . . 
The elderly soldier experiences a moment when past and present merge, as the setting prompts his memory: "Strange visions come, on rushing wing, / To bear me to the battle back." The writer's invocation of "the consecrated plain" of Bunker Hill sanctified by the "painful toil" of an "untaught army" emphasizes the democratic heroism of times past. ${ }^{22}$

This interpretation of the Revolution, however, competed with more abstract versions that minimized ordinary soldiers' contributions and the intimate ways in which families and communities celebrated the past. In 1825, the fiftieth anniversary of the battle at Bunker Hill, the Marquis de Lafayette arrived to lay the monument's cornerstone in Boston. Daniel Webster spoke at this commemorative event with two hundred revolutionary veterans in attendance. The orator reminded his audience of the imminent passing of generations but also emphasized the material advances and prosperity apparently enjoyed by all. To Webster, hope and optimism, not death and loss, comprised the thematic elements of the nation's memory. Returning to Boston in 1843 to speak at the monument's completion, he observed that "if the Revolution was an era in the history of man favorable to human happiness, if it was an event which marked the progress of man all over the world from despotism to liberty, then this monument is not raised without cause." As a master narrator of nationalist themes, Webster sought to replace the common veterans' role as oral transmitters of the revolutionary past. The monument, he went on, had national significance as well, from which citizens' patriotism for the republic would prevail over "family associations . . . local attachment and private affection." The orator deferred to the monument itself as representative of past sacrifices and future promises: "I have spoken of the loftiness of its purpose [in 1825]. ... It is itself the orator on this occasion." He then concluded his speech praising the virtues of George Washington. If the faces and deeds of individual veterans faded over time, the Bunker Hill monument and Washington's memory served for Webster as the appropriate embodiments of what Americans should remember about their revolutionary past. $^{23}$

Throughout the nineteenth century, popular writings on the Revolution did rejoice in feelings of nationalist triumph and expressed sole gratitude for Washington's determination and guidance. But when surviving veterans were more abundant and reliving their memories, Niles' Weekly Register editorialized in 1822: "As applied to the business of revolution, there were many Washingtons, or those who would have performed the part of 'fathers of their country.' Most excellent he wasbut all excellence was not in his own single person." Downplaying the transcendent influence of Washington was not Hezekiah Niles's purpose here. Rather, his intent was to uplift others' contributions to the founder's level of accomplishments. In his Legends of the American Revolution (1847), George Lippard agreed: "The patriotism of the humblest 
freeman, has been as dear to me ... as the moral grandeur of Washington, or the chivalric daring of La Fayette." The contexts of remembrance also had not evolved at this point when more bitter regional contests by the 1850 s required an encompassing symbol like Washington to appeal to people's loyalties to the Union. Democratically inspired, these poems avoided larger political issues and instead grounded intimate memories within the common sacrifices for the nation. ${ }^{24}$

Most popular poetry shared Daniel Webster's enthusiasm for the nation's past, but before the 1850s such work persisted in emphasizing the personal, familial, and local aspects of that history. These poems focused on the ordinariness of revolutionary veterans, paying tribute to their exceptionally heroic deeds without the shadow of leadership. An 1838 poem published in The Knickerbocker, "Lines to Our Surviving Revolutionary Soldiers," in voicing its gratitude to the veteran generation, anticipates similar themes that arise in "The Centenarian's Story": "We owe to you, time-honored race, / And those your mates, whose dwelling-place / Is now the narrow grave." ${ }^{25}$ Other poets also commemorated the revolutionaries' deaths in past battles and in old age, though in more contrived ways than Whitman. In an 1839 Democratic Review, the author of "Departed Heroes" boastfully sees the past and present generations sharing the honor of a prosperous nation: "Freeman, to live or die / On our beloved soil, / They were as we." The writer urges his audience to both mourn and celebrate the revolutionary generations by bellowing out their pride over the natural landscape:

Shout for the mighty men,

Who sleep in our father-land,

(Blest be their grave.)

Shout over hill and glen,

And over rock and strand,-

Shout for the brave. ${ }^{26}$

In another poem from the Democratic Review, "Ode for the Fourth of July" (1855), the writer combines the vision of long-dead bodies fertilizing the landscape with his call to trumpet the revolutionaries' historical deeds all over the nation:

Where once the hardy foemen met

With glittering sword and bayonet;

Where horse and rider, cold in death,

Lay stretched upon the bloody heath:

Long since the waving grass has grown,

And flowers have wreathed each bleaching bone.

...

Let East and West, and South and North

Raise a triumphant voice.

T'was on this day our Fathers broke

The British monarch's galling yoke. . . ${ }^{27}$ 
Doubtless, these poems may now read more arduously or humorously than intended. To a certain extent, however, they do reveal the thematic roots of what would soon after appear in "The Centenarian's Story."

In The Knickerbocker's “An Old Man's Reminiscence” (1843), a granddaughter of a revolutionary officer converts remembrances into poetic fancy, delineating the grandfather's thoughts when returning fifty years later to a house in which he was married at the end of the Revolution. In one stanza, the narrator ponders questions about the elderly soldier's reactions to revisiting the site:

What were his thoughts that hour, which thus awakened many a sigh?

What brought the shadow o'er his brow, the moisture to his eye?

What in that old familiar place had power to touch his heart,

To call that cloud of sorrow up, and bid that tear-drop start? ${ }^{28}$

Contemplating her grandfather's memories in this way allows the writer to deepen her sense of gratitude and sympathy for his past sacrifices. These personal remembrances also chart the beginnings of a new postrevolutionary family, now including the poet as she records this episode for future members.

Also from The Knickerbocker, "The Veteran of Seventy-Six" (1854) relives the adventures of an aged revolutionary veteran as he aroused the patriotism of those venturing off to fight in the Battle of New Orleans during the War of 1812 . This poem coincides historically and thematically with how the Revolution would later provide meaning for Whitman's Civil War. In one instance, the old man recollects for a younger generation of soldiers a dire moment that later would contribute to an eventual victory:

By the smouldering fires of Valley-Forge I saw the spectral train, Under canvas-rags, and pine-boughs, on the dreary, miry plain; War-worn, famished, unprotected, in the chill of December rain, Yet, undaunted and defiant. . . . ${ }^{29}$

Although this poem appeared in the 1850 s, when more and more writers valorized George Washington's memory in their desires to stave off disunion, the sense of leadership again is missing here. Washington may have been the foremost example of perseverance for the patriot army at Valley Forge. But the poet here avoids mentioning the general's exemplary determination, a rare approach by this time, and highlights instead the democratic hardiness of the common soldiery. In one way or another, these writers presented themselves as artistic mediators who linked past, present, and future generations through their poetry, publicizing the revolutionary past as inspired by the people, who were often members of their family or community. 
In The Ecstatic Whitman (1986), George Hutchinson presents a brief but intriguing argument for the importance of "The Centenarian's Story" within the overall structure of Drum-Taps. He writes: "If Whitman found in the opening of the secession conflict reason for beating the drum and comparing contemporary history with the heroic past, '[The] Centenarian's Story' also records the first glimmering in the North of what war might bring in loss and sorrow. The poem thus marks an important transition in Drum-Taps as the cluster is traditionally perceived." 30 While Hutchinson demarcates the poem's internal relationship with other pieces within the collection, I want instead to elucidate its external involvement with popular culture. That is, "The Centenarian's Story" reveals Whitman's engagement with all of the previously outlined components of historical memory transmitted through popular literature, thereby contributing to his veering in more conventional directions as poet-historian. Here "The Centenarian's Story" marks not only the poetic transitions within Drum-Taps but also the shifting attitudes toward the revolutionary past portrayed in other writings over the several decades before the Civil War.

The poem's structure consists of three parts: the first is narrated by a young Union Army soldier; the second is an aged veteran's memory of the Battle of Brooklyn Heights on August 27, 1776; and the last (entitled "Terminus") returns to the youthful recruit with his take on the cultural magnitude of the centenarian's oral history.

In the beginning section, the Union Army recruit discloses himself in the poem's subtitle as a "Volunteer of 1861-2" who assists the "old Revolutionary" in their walk along a parade ground in Brooklyn, New York. On this pleasant afternoon, crowds assemble to cheer drilling federal troops, some of whom will depart for the front the next day. As the recruit and the centenarian observe the soldiers preparing for war, the youth remarks to his aged companion: "Your faculties serve you, and presently I must have them serve me . . . / You to speak in your turn, and I to listen and tell." 31 The narrator acknowledges his place within the wider realms of memory that extend into the past and future. His telling, or rather reinterpreting, of the centenarian's tale (after heeding it in the second section) will then appear in the poem's third part for other generations of listeners.

Strolling up a hill, the younger man exchanges his physical aid for the elder's more important assistance in reconstructing memories and a sense of the past for his listener's benefit. The youth poses various questions to entertain the centenarian, at one point becoming confused at his sudden shivering: 
Do you hear the officers giving their orders?

Do you hear the clank of the muskets?

Why what comes over you now old man?

Why do you tremble and clutch my hand so convulsively?

The troops are but drilling, they are yet surrounded with smiles,

Around them at hand the well-drest friends and the women,

While splendid and warm the afternoon sun shines down,

Green the midsummer verdure and fresh blows the dallying breeze,

O'er proud and peaceful cities and arm of the sea between. (LGV, 2:469-470)

The "midsummer verdure" and the "proud and peaceful cities" encourage the narrator's sense of optimism and innocence when taking in the scene below. It even leads him to misconstrue the centenarian's curious trembling, which appears overwrought if not plain silly to the youth. Here Whitman may have been mildly critiquing the confident outburst of patriotism that erupted in the opening days of the Civil War. Although this first section of "The Centenarian's Story" coincides with the martial tones of the beginning poems in Drum-Taps, it also portrays a sense of fervor without complete understanding on the young soldier's part. M. Wynn Thomas persuasively claims that despite their jingoistic qualities works like "First O Songs for a Prelude," "Song of the Banner at Daybreak," and "Beat! Beat! Drums!" disclose Whitman's deeper ambivalent welcoming of the war to reform the democratic state. ${ }^{32}$ The first section of "The Centenarian's Story" reflects as well Whitman's veiled discomfort with the initial preparations of war.

This attitude emerges more clearly in the poem's second part, entitled "The Centenarian," when the old man explains his excitement to his young companion: their present spot is one in which revolutionary soldiers had once marched and fought. As the veteran elaborates: "My blind eyes even as I speak behold it re-peopled from graves . . . / Here we lay encamp'd, it was this time in summer also" (LGV, 2:470, 471). By recounting the military engagement in which the British army routed the inexperienced Americans, the old veteran's stories contribute to the young man's own identity and historical knowledge, linking past and present uncertainties of the Revolution and Civil War's beginnings. The patriots' setback on Brooklyn Heights implicitly parallels the Union's loss to the Confederate forces at the first battle at Bull Run in 1861 . Both confrontations test the participants' resolve in seeing through the longer struggles that lay ahead..$^{33}$

In creating the centenarian, Whitman plays into the earlier structures and themes of oral histories and poetry presented in popular literature, in which revolutionary survivors lent poise and stability to later troubling times. At the heart of his recitation, the veteran extends his listener's knowledge about the costs of war. The youth learns about the revolutionary past through a sequence of events in the centenarian's tale, in which democratic ideals are asserted and then challenged by the 
blood and smoke of battle. The old man begins: "As I talk I remember all, I remember the Declaration, / It was read here, the whole army paraded, it was read to us here . .." as George Washington presided over his troops. By openly proclaiming their freedom and equality, the colonists incurred the wrath of empire, as the veteran resumes:

'Twas a bold act then-the English war-ships had just arrived, We could watch down the lower bay where they lay at anchor, And the transports swarming with soldiers.

A few days more and they landed, and then the battle. ( $L G V, 2: 471)$

Recounting how the American colonists vainly attempted to defend Brooklyn with an anguished Washington looking on, the centenarian then insists to his young charge: "I tell not the whole of the battle, / But one brigade early in the forenoon order'd forward to engage the redcoats. ..." He continues:

Who do you think that was marching steadily sternly confronting death?

It was the brigade of the youngest men, two thousand strong,

Rais'd in Virginia and Maryland, and most of them known personally to the

General. (LGV, 2:471)

Gently rebuking his young listener's earlier self-confidence at the Union Army drills, the centenarian states of the confrontation at Brooklyn Heights:

That and here my General's first battle,

No women looking on nor sunshine to bask in, it did not conclude with applause, Nobody clapp'd hands here then. ( $L G V, 2: 472)$

By focusing on this one instance in which Southern soldiers bore the heaviest fighting, the elderly veteran clarifies for his listener the past martial sacrifices that indirectly would arouse compassion for and forgiveness of present enemies. The veteran's own approaching mortality lends greater importance to his memories, as he personalizes both in 1776 and 1861 the numerous deaths of young soldiers, North and South. All have suffered or will endure casualties in their honoring of the nation's founding principles. Yet, this interpretation verges on identifying with the South's political goals in disunion. Opposing the North's threats to their slave society, secessionists appropriated the ideals embodied in the Declaration, which their forefathers helped fashion, in order to justify their actions. As several critics have pointed out, Whitman was not entirely sympathetic to either the North or South. He assigned blame to both regions for disabling the democratic process and thus fomenting the Civil War. But this message would appear terribly ironic to the veteran's companion, that young volunteer starting off to fight the de- 
scendants of these earlier Southern patriots. ${ }^{34}$ The centenarian, however, uses the moment only to express sorrow for the past and upcoming deaths of those born from generations once united against the British crown: "But $\mathrm{O}$ from the hills how the cannon were thinning and thinning them! / It sickens me yet, that slaughter!" (LGV, 2:472). Particularly at the Civil War's conclusion-taking into account the context of Drum-Taps' initial publication in 1865-Whitman implies to the reader that neither region had cause to blame the other any further.

"The Sleepers" in Leaves of Grass anticipates this attitude, as Whitman imagines Washington's retreat from Brooklyn as a moment of revolutionary despair and mourning. The general "sees the slaughter of the southern braves confided to him by their parents." Joining their patriot brethren from the North, these "southern braves" willingly march, fight, and die too for a noble cause. As sectional tensions intensified during the mid-1850s, Whitman offered the hopeful lesson from the past in which war and nation-building subsumed the different regional affiliations of past soldier-comrades. The paternal figure of Washington becomes significant as a national and democratic symbol that embraces all patriot sufferings. As Whitman writes in "The Sleepers," the general "cannot repress the weeping drops" at the casualties incurred. To the bard, Washington bemoans the loss of life in battle, but in a prophetic sense, the potential loss of union as well. Yet, at the Revolution's end, Whitman transforms the general's tears in this early defeat to "the wet cheeks" of his fellow officers that Washington kisses in farewell when peace and independence are finally assured ( $L G V, 1: 115)$.

The centenarian's story returns to and expands on the same scene first presented in "The Sleepers." In the aged veteran's recounting, the patriots under Washington's heroic leadership evacuate Brooklyn with the British close on their heels. As in "The Sleepers," this tale brims more with determination than despair, a moral for those who might lose faith in the democratic experiment during the Civil War. The centenarian ends his tale on this note:

Every one else seem'd fill'd with gloom, Many no doubt thought of capitulation.

But when my General pass'd me,

As he stood in his boat and look'd toward the coming sun,

I saw something different from capitulation. ( $L G V, 2: 473$ )

The example of Washington and his troops' resolve to overcome disaster quite clearly offers a historical parallel to and model of behavior for Whitman's present. Sooner or later, the poet hinted, feelings of dread would transform with "the coming sun" into the joys and relief of victory. 
By emphasizing Washington's stalwart presence in the mayhem of battle, Whitman resorted to a common strategy of using the founder as a symbolic center of gravity for the disuniting nation. The poet had preferred to idolize Washington over the other founders since his boyhood days. He even admonished the South in a later poem appearing in 1872, "Virginia - The West," in which Washington, though an esteemed native son of Virginia, was more importantly (should Southerners forget) the founding father of the entire nation. ${ }^{35}$ Especially during the 1850 s, Washington as Southerner turned nationalist provided Northern writers with the basis for maintaining the Union amid sectional rancor. In five volumes of his biography Life of George Washington (18551859), Washington Irving presented a brazenly national account in the form of the founder's life that would hold the republic together throughout history. He notably concludes the fifth and last volume on Washington in 1859:

With us his memory remains a national property, where all sympathies throughout our widely-extended and diversified empire meet in unison. Under all dissensions and amid all the storms of party, his precepts and example speak to us from the grave with a paternal appeal; and his name - by all revered - forms a universal tie of brotherhooda watchword of our Union. ${ }^{36}$

Invoking the spirit of the revolutionary past, Irving created a sacred historical narrative by which to bind the splintering nation, appealing to its conscience and its loyalty to Washington's memory.

By producing a life of such grand proportions, Irving contributed to his own fame as a creator of national memory. "WASHINGTON and WASHINGTON IRVING will walk down the corridors of Time together," one reviewer boasted in The Knickerbocker, playing on the repetitive naming of subject and author. Irving's task as biographer, however, proceeded beyond recording the past and being celebrated for it; he would also convey the lessons presented by his subject's example. G.W. Greene (G.W. naturally meaning "George Washington") asserted in his review: "The historian of Washington is the great teacher of the nation." He added that readers "should rise from the volume with the whole of the wondrous history imprinted upon our memories." In the Democratic Review, another reviewer of Irving's biography did notice the apparent ambiguity of hero-worship in a supposedly egalitarian society. The writer admitted that "the prudent jealousy of a republic forbids that her free citizens should unduly exalt . . . any fallible and ambitious fellow-citizen." But he also saw Washington as "the best exemplar of the best and most prominent features of American character": virtue, honor, sacrifice, piety, and industry, among other traits. With sectional disputes between North and South rising to the political foreground, the reviewer commended Irving, noting that the biography was "by far the most national of all his works." In effect, the founding 
father embodied features with which, ideally, all Americans could identify. ${ }^{37}$

In 1856, a different writer for the Democratic Review appraised the private correspondence of the Continental Congress and reached a similar conclusion about the sanctity of the Union and George Washington's memory. "Every reminiscence of our Revolutionary times and of those immediately succeeding them," the essayist noted, "evince, with irresistible force, the high value, indeed the essential necessity of the Union of the people of the several States under a Federal government based on a national constitution." As sectional tensions increased over slavery, western expansion, and popular sovereignty, memories of the Revolution supplied the only hope to keep the republic from fracturing: "It was a union of the people of the United States as one people, which carried our fathers through the Revolution! This alone can preserve our nation from discord, and political anarchy and despotism!" Countering any attempt especially from Southerners to disrupt appeals for an integrated historical memory, the Democratic Review editorial urged a greater appreciation of the revolutionary past from which to draw political and moral instruction. The article concluded by lauding the members of that first Congress who created the new national government "with Washington at its head." 38

These interrelated issues of leadership, unity, and memory also appear in poetry. In the previously mentioned "Ode for the Fourth of July" (1855), the writer for the Democratic Review celebrates revolutionary war veterans who told of past glories as the central heroes in his work. To his present-day readers, however, the poet also makes clear the lessons about the roots of their prosperity:

He can enjoy without regret,

Spoils that the gallant dead have won:

De Kalb, Pulaski, Lafayette,

Led by the godlike Washington.

Though stilted and cliché in form and language, the writer emphasizes how the Revolution was the world's cause by listing European leaders who had lent their support to the war under Washington's direction. The Revolution's ideals would then become a suitable American export to transform other nations in democracy's image. But first, the poet introduces his case for a persevering union:

From the far snow-capped hills of Maine,

To Mexic[o]'s burning clime,

Rises on high a glorious strain,

We're brothers for all time. . . . ${ }^{39}$ 
Here he presents the nation's geographic reach and material wealth, measured by its northern and southern-most regions, as the entire populace's shared inheritance. To reject this bounty, the writer insinuates, would be to refuse what the revolutionaries, both founding fathers and common soldiers alike, graciously offered to their heirs. Yet, unacknowledged in this celebratory moment is the poet's embrace of American imperial expansion, which ironically intensified the spread of slavery and thus the possibilities for disunion.

Although the Civil War transformed how popular writings responded to the Revolution, authors still retained from the antebellum period several important elements of assessing their historical memories. As intermediaries between the revolutionary past and the sectional conflict, they sought to establish their own place in future generations' minds during and after the Civil War. These writers usually lacked the more encompassing and even ambivalent views Whitman espoused about the war since they differed from the poet in intent and audience. For instance, in one children's book, Winnie and Walter's Evening Talks with Their Father About Old Times (1861), a fictitious father tells his two offspring about his own youthful days in the 1820s. Published in Boston on the eve of the Civil War, the text serves to remind Northern readers of their patriotic legacies. The father recounts that people who had lived through and after the Revolution "were very common and very easily found" during his boyhood. To his attentive children, the patriarch relives how delighted he was "to hear them talk about those times of war and trouble and excitement through which they had passed." This observation parallels Winnie and Walter's tension-ridden era. Their father reassures them that the emerging nation did and would continue to survive its greatest trials and afflictions. He even recalls a close acquaintance who had fought in the Revolution. Expounding on the old neighbor's memories of war, the father reminisces about lessons learned in his childhood when the aged veteran told him "about God, and about human life,- - about what I ought to be and to do, and I shall never forget these conversations." The father's primary lessons emphasize the continual reverence for the revolutionaries and the earnest imitation of their virtues and self-sacrifice. The post-revolutionary generations, in turn, not only had to set these goals for themselves but for their own children as well. The perpetuation of inspirational memories and teachings would then be ensured throughout time, generation after generation, to keep the Union whole and sacred. ${ }^{40}$

In The Last Men of the Revolution (1864), the Reverend E.B. Hillard identified and located seven centenarians in the North, interviewed them, and delighted in preserving their stories for later generations. He accentuated his generations' affiliation with the revolutionaries: "Our own are the last eyes that will look on men who looked on Washington; our ears the last that will hear the living voices of those who heard his words." 
"Henceforth," he declared, "the American Revolution will be known among men by the silent record of history alone." To Hillard, these revolutionary war veterans served not only as historical actors, but also as democratic intermediaries between the nineteenth-century populace and the greatness of Washington. Future citizens would then gain access, at least indirectly, to the founding father through those of Hillard's generation. As a minister, too, Hillard unsurprisingly accented the centenarians' religious convictions that bolstered their sympathies with the Union. One of his subjects, Daniel Waldo, was a pastor himself who "greatly desir[ed] to live till the rebellion should be suppressed . . ., [having] implicit faith in the ultimate success of the Union arms and the re-establishment of the authority of National Government over all the states." The text drew no attention to the veteran's ironic and problematic use of "rebellion," which implicitly linked the revolutionaries' act to Southern secession. Like previous writers in the midst of an indeterminate present and future, Hillard instead associated Washington's memory as well as the revolutionary veterans' reassuring presence and longevity with a glorified past. ${ }^{41}$

Within "Terminus," the third and last section of "The Centenarian's Story," Whitman's young soldier evaluates the larger significance of the veteran's tale of the battle at Brooklyn Heights. The narrator acquires not only a personalized history and sense of mission from the centenarian, but also a vaster appreciation for a physical environment that he had taken for granted. As charted earlier, conventional poetry before the Civil War also disclosed how historic battlefields impelled chroniclers to assess the import of past revolutionary struggles and sacrifices. Though formulaic too, Whitman's conclusion does reveal some of his unique touches. In cadences reminiscent of "Crossing Brooklyn Ferry" (1856), the Union soldier wonders:

And is this the ground Washington trod?

And these waters I listlessly daily cross, are these the waters he cross'd,

As resolute in defeat as other generals in their proudest triumphs?

...

$\mathrm{Ah}$, hills and slopes of Brooklyn! I perceive you are more valuable than your owners supposed;

In the midst of you stands an encampment very old,

Stands forever the camp of that dead brigade. ( $L G V, 2: 473,474$ )

From now on, as the young man traverses the river or gazes on the hills, he will be reminded to preserve and convey the tale of historic sacrifices. ${ }^{42}$ The last stanza also marks a shift away from Washington as the commander of disparate factions within the nation. Here Whitman turns instead to the overwhelming sense of death, recorded and presaged by the centenarian, as the central, unifying experience that all soldiers faced during the Revolution and the Civil War. Later poems in Drum-Taps build on this transition point. In "Ashes of Soldiers," he grieves: 
Ashes of soldiers South or North,

$\ldots$

Noiseless as mists and vapors,

From their graves in the trenches ascending,

From cemeteries all through Virginia and Tennessee,

From every point of the compass out of the countless graves,

In the wafted clouds, in myriads large, or squads of twos or threes or single ones they come,

And silently gather round me. ( $L G V, 2: 510)$

Likewise, in "Pensive on Her Dead Gazing," the poet writes:

My dead absorb or South or North — my young men's bodies absorb, and their precious precious blood,

Which holding in trust for me faithfully back again give me many a year hence,

In unseen essence and odor of surface and grass, centuries hence. . . ( $L G V, 2: 527)$

In "The Centenarian's Story," the Southern revolutionaries interred within Brooklyn's hills offer sacrifices for the nation similar to those of the Civil War dead in the "cemeteries all through Virginia and Tennessee" or in the "unseen essence and odor of surface and grass" of the latter two poems. The myriad burial grounds in all three poems emit spirits of one sort or another that urge the poems' narrators to conduct memories of the dead beyond the confines of topography or historical chronology.

In "The Centenarian's Story," time and narratives past become fused and perpetuated in the narrator's voice: "The two, the past and present, have interchanged, / I myself as connecter, as chansonnier of a great future, am now speaking" ( $L G V, 2: 473$ ). Prodded onward by the centenarian's recollection, the young recruit then defines his own mission not only temporally but geographically as well: "I must copy the story, and send it eastward and westward" (LGV, 2:474). Whitman's choice of directions is telling. Rather than transmitting his tale northward and southward, the poet avoids sectional acrimony by facing eastward toward both Northern and Southern states, and westward toward redemption, expansion, and new beginnings for all. In the aftermath of death and bereavement, he optimistically foresees a national rebirth based on the old revolutionary veteran's example and memories. Immediately following "The Centenarian's Story" in the 1865 edition of Drum-Taps, Whitman reinforces this sense of reunion and revitalization in "Pioneers! O Pioneers!" when he proclaims:

O you youths, Western youths,

So impatient, full of action, full of manly pride and friendship,

Plain I see you Western youths, see you tramping with the foremost,

Pioneers! O Pioneers! 
From Nebraska, from Arkansas,

Central inland race are we, from Missouri, with the continental blood intervein'd, All the hands of comrades clasping, all the Southern, all the Northern,

Pioneers! O pioneers! ( $L G V, 2: 475,476)$

The young recruit in "The Centenarian's Story" hardly loses sight of "a great future," notwithstanding the Civil War's destruction and postwar uncertainty. From a tactic elaborated throughout antebellum popular poetry, he places his faith in the everlasting principles of the Revolution and its few remaining participants. But the Union soldier's energy, optimism, and camaraderie - traits developed historically and culturally by the "Western youths" from "Pioneers! O Pioneers!"-also lead him away from despairing for the nation.

As a participant in the trends of collective remembrance located in popular literature, Whitman used its conventions and proceeded beyond them to transmit a similar impression of assurance and stability from the past. Like other pieces in Drum-Taps, "The Centenarian's Story" certainly displays Whitman's ambition as poet-historian to give artistic meaning to the Civil War. What makes this poem distinctive from the rest, however, is his reliance on a centenarian figure at a time when practically none survived. Perhaps Whitman felt that the revolutionary principles embodied in the centenarian, while long-lived, were not only fading but also creating a new phase of history through the Civil War. If so, "The Centenarian's Story" reveals this merging of old and new attitudes. Whitman adapted the themes and structures of popular literature that celebrated a diminishing past recounted through personalized histories; but his poem also embraced the changing dynamics by which the nation's citizenry understood that past. He tapped into the tradition of oral storytelling commonly appearing in other poetry during the 1830 s and 1840 s that celebrated the more ordinary revolutionaries as a democratic force in history. While the poem as a whole incorporated this method and theme of chronicling the revolutionary past, the centenarian's tale of battle and the narrator's "Terminus" also venerated George Washington as a coinciding symbol of democracy, a more visible strategy in the $1850 \mathrm{~s}$. Whitman included these popular conventions and their altering levels of democratic influences within his poem during the radical circumstances of civil war, reflecting and transforming how other writers lent cultural significance to the Revolution. Indeed, by expounding on the perils and possibilities of a conflicted nation, he portrayed the Civil War in "The Centenarian's Story" as a revolutionary reenactment - an intricate replaying with new variations-of challenges and heroics past.

The University of Alabama 


\section{NOTES}

1 For a few examples of recent scholarship on Whitman and the Civil War, see George Hutchinson, "Race and the Family Romance: Whitman's Civil War," Walt Whitman Quarterly Review 20 (Winter/Spring 2003), 134-150; Stephen John Mack, The Pragmatic Whitman: Reimagining American Democracy (Iowa City: University of Iowa Press, 2002), 77-132; Roy Morris, Jr., The Better Angel: Walt Whitman in the Civil War (New York: Oxford University Press, 2000); Ed Folsom, "Lucifer and Ethiopia: Whitman, Race, and Poetics Before the Civil War and After," in A Historical Guide to Walt Whitman, ed. David S. Reynolds (New York: Oxford University Press, 2000), 45-95; Robert Leigh Davis, Whitman and the Romance of Medicine (Berkeley: University of California Press, 1997); Luke Mancuso, The Strange Sad War Revolving: Walt Whitman, Reconstruction, and the Emergence of Black Citizenship, 1865-1876 (Columbia: Camden House, 1997), 1-15; M. Wynn Thomas, "Fratricide and Brotherly Love: Whitman and the Civil War," in The Cambridge Companion to Walt Whitman, ed. Ezra Greenspan (Cambridge: Cambridge University Press, 1995), 27-44.

2 David S. Reynolds, Beneath the American Renaissance: The Subversive Imagination in the Age of Emerson and Melville (Cambridge: Harvard University Press, 1988); Walt Whitman's America: A Cultural Biography (New York: Alfred A. Knopf, 1995), 457470.

3 Betsy Erkkila, Whitman the Political Poet (New York: Oxford University Press, 1989), 205, 211-212.

4 Erkkila, Whitman the Political Poet, 191, 202; Mancuso, The Strange Sad War Revolving, 1-10; Daniel Aaron, "Whitman and the Founding Fathers," in Walt Whitman of Mickle Street: A Centennial Collection, ed. Geoffrey M. Sill (Knoxville: University of Tennessee Press, 1994), 46-53.

5 See M. Wynn Thomas, The Lunar Light of Whitman's Poetry (Cambridge: Harvard University Press, 1987), 178-204.

6 Refer to George Forgie, Patricide in the House Divided: A Psychological Interpretation of Lincoln and His Age (New York: W.W. Norton \& Co., 1979). Although briefly noting the interplay of generational memories on the nation's population at large, Forgie concentrates mainly on how the transmission of revolutionary legacies through a genealogical framework affected political leadership in the nineteenth century.

7 In The Presence of the Past: Popular Uses of History in American Life (New York: Columbia University Press, 1998), Roy Rosenzweig and David Thelen conducted surveys and interviews to find out how people across the nation developed their historical sensibilities. A great majority of them responded that family histories were for them the main wellsprings of the past. Viewed as trustworthy sources of information, elders and other community acquaintances made the past intimate, recounting stories and reminiscences that drew family members to each other. Personal artifacts such as photographs and scrapbooks, letters and journals - all linked by oral histories - served as important mnemonic devices that marked the continuities and changes in people's lives. Regarding a great historical event-here, the Second World War-many of the survey respondents recollected stories about it that had little to do with "the triumphal national narrative favored by those who write textbooks or advocate history as a means of teaching patriotism or civics." Avoiding the larger historical frameworks learned in their schooling, the participants instead emphasized their familial pasts to come to terms with national events. As the historians concluded: "Americans engaged larger pasts on their own terms" (116). This point, I think, puts into better perspective how people in the antebellum era remembered their Revolution. 
8 Maurice Halbwachs, The Collective Memory (1950; rpt. New York: Harper \& Row, 1980), 63-68.

9 Thomas, "Fratricide and Brotherly Love," 27-44; Hutchinson, "Race and the Family Romance," 134-150.

10 "The Pensioner's Death," The Casket 2 (October 1827), 387; "A Celebration," The Lowell Offering new ser. 1 (1841), 20; Lewis R. Hamersly, "Thoughts and Reminiscences for the Fourth of July," Godey's Lady's Book and Magazine 27 (July 1843), 41.

11 “Independence," Niles' Weekly Register 18 (July 1, 1820), 313.

12 Some of the literature on the aged in American history includes: Thomas R. Cole, The fourney of Life: A Cultural History of Aging in America (Cambridge: Cambridge University Press, 1992); W. Andrew Achenbaum, Old Age in the New Land: The American Experience Since 1790 (Baltimore: Johns Hopkins University Press, 1978); David Hackett Fischer, Growing Old in America (New York: Oxford University Press, 1978); Carole Haber, Beyond Sixty-Five: The Dilemma of Old Age in America's Past (Cambridge: Cambridge University Press, 1983). For insights into the extension of identities beyond one's life, see John Kotre, Outliving the Self: Generativity and the Interpretation of Lives (Baltimore: Johns Hopkins University Press, 1984).

13 Mrs. Sarah J. Hale, Sketches of American Character (Boston: Putnam \& Hunt, and Carter \& Hendee, 1829), 27; Hamersly, "Thoughts and Reminiscences for the Fourth of July," 42.

14 Niles’ Weekly Register 31 (September 23, 1826), 57.

15 Abraham Lincoln, “Address to the Young Men's Lyceum of Springfield, Illinois," Abraham Lincoln: Speeches and Writings, 1832-1858, ed. Don E. Fehrenbacher (New York: Library of America, 1989), 36.

16 "The Men of Seventy-Six," Southern Literary Messenger 3 (August 1837), 473.

17 Niles’ Weekly Register 31 (November 18, 1826), 180; 32 (July 21, 1827), 343.

18 Milford Bard, "The American Soldier," The Casket 1 (October 1826), 315, 316.

19 Hale, Sketches of American Character, 28; S[amuel] G[riswold] Goodrich, Recollections of a Lifetime, vol. 1 (1856; Detroit: Gale Research, 1967), 22, 23; Goodrich, The Tales of Peter Parley About America, 2nd ed. (Boston: S.G. Goodrich \& Co., 1829), 9; Walter Whitman, "The Last of the Sacred Army," United States Magazine and Democratic Review 10 (March 1842), 263-264.

20 There is no evidence that Whitman read the specific poems under analysis here, but they do contain the prevalent conventional themes and rhetorical styles that repeatedly appeared throughout volumes of books, newspapers, and periodicals, making it hard to miss for Whitman or anyone else keen on popular genres.

21 Hannah F. Gould, "The Veteran and the Child," Atkinson's Casket 9 (January 1834), 25.

22 Melzar Gardner, "The Old Soldier Revisiting the Scene of His Early Struggles," United States Magazine and Democratic Review 3 (September 1838), 26-27.

23 Daniel Webster, The Works of Daniel Webster, vol. 1 (Boston: Charles C. Little and James Brown, 1851), 86, 89, 92. 
24 Niles' Weekly Register 22 (August 3, 1822), 354; George Lippard, The Legends of the American Revolution, rev. ed. (1847; Philadelphia: Leary, Stuart \& Co., 1876), 11 12 .

25 Le Chansonnier, "Lines to Our Surviving Revolutionary Soldiers," The Knickerbocker 11 (March 1838), 232.

26 T.H.H., "Departed Heroes," United States Magazine and Democratic Review 6 (October 1839), 338.

27 Colonel Eidolon, “Ode for the Fourth of July," United States Review 36 (July 1855), 44.

28 M.N.M., “An Old Man's Reminiscence,” The Knickerbocker 22 (October 1843), 298.

29 Richard Hayward, "The Veteran of Seventy-Six," The Knickerbocker 43 (January 1854), 41.

30 George Hutchinson, The Ecstatic Whitman: Literary Shamanism and the Crisis of the Union (Columbus: Ohio State University Press, 1986), 141.

31 Walt Whitman, "The Centenarian's Story," in Leaves of Grass: A Textual Variorum of the Printed Poems, ed. Sculley Bradley, Harold W. Blodgett, Arthur Golden, and William White (New York: New York University Press, 1980), 2:469, 470; hereafter $L G V$.

32 Thomas, The Lunar Light of Whitman's Poetry, 192-200.

33 Hutchinson, The Ecstatic Whitman, 141.

34 Reynolds, Walt Whitman's America, 414-416; Thomas, "Fratricide and Brotherly Love," 29-30; Morris, The Better Angel, 81-82.

35 Aaron, "Whitman and the Founding Fathers," 47-49; Thomas, "Fratricide and Brotherly Love," 29-30.

36 Washington Irving, Life of George Washington, ed. Allen Guttman and James A. Sappenfield (Boston: Twayne Publishers, 1982), 5:475.

37 "Life of George Washington. By Washington Irving," The Knickerbocker 46 (July 1855), 74; G.W. Greene quoted in Critical Essays on Washington Irving, ed. Ralph M. Aderman (Boston: G.K. Hall \& Co., 1990), 151; "Irving's Life of Washington," The United States Review 36 (July 1855), 66, 67.

38 "Reminiscences of the American Revolution and Times Succeeding," The United States Democratic Review 38 (November 1856), 313, 315, 323-324.

39 "Ode for the Fourth of July," 45.

40 [Increase N. Tarbox], Winnie and Walter's Evening Talks with Their Father About Old Times (Boston: J.E. Tilton \& Company, 1861), 19, 23-24.

41 Rev. E.B. Hillard, The Last Men of the Revolution (Hartford: N.A. \& R.A. Moore, 1864), 4, 29.

42 Thomas, The Lunar Light of Whitman's Poetry, 253-254. 